\title{
PEMBERDAYAAN SUMBER DAYA LOKAL DALAM PENGELOLAAN SEKTOR INDUSTRI KREATIF DI KECAMATAN BANDA SAKTI KOTA LHOKSEUMAWE: STUDI KUALITATIF ATAS PERAN CORPORATE SOCIAL RESPONSIBILITY (CSR) PT. PERTAMINA (PERSERO) MARKETING OPERATION REGION (MOR) I - TERMINAL BAHAN BAKAR MINYAK (TBBM) LHOKSEUMAWE
}

\author{
Joko Suhariyanto $^{1 *}$, Andri Zainal ${ }^{1}$, Kustoro Budiarta ${ }^{1}$ \\ ${ }^{I}$ Fakultas Ekonomi, Universitas Negeri Medan, Medan, Indonesia \\ "Penulis Korespondensi: dj.ok04286@gmail.com
}

\begin{abstract}
Abstrak
Makalah ini merupakan kajian kualitatif atas pelaksanaan CSR oleh PT. PERTAMINA (Persero) MOR I - TBBM Lhokseumawe yang dipusatkan di Kecamatan Banda Sakti Kota Lhokseumawe pada tahun 2017. Realisasi CSR yang dimaksud meliputi kegiatan: 1) Pengembangan Sentra Industri Ikan Kering; 2) Peningkatan Kapasitas Kelompok Masyarakat Peduli Wisata: Workshop Kebencanaan dan Search and Rescue (SAR) bagi Relawan dan Pemandu Wisata; 3) Pelayanan Kesehatan: Pelatihan Bantuan Hidup Dasar (BHD) untuk Relawan. 4) Pengembangan Usaha Souvenir Decopage; 5) Pelatihan Pengembangan Wirausaha Baru di Bidang Sablon dan Reparasi Mesin Penyejuk Udara (Air Conditioner/AC) Bagi Angkatan Kerja Produktif Putus Sekolah. Merujuk kepada capaian dari pelaksanaan kegiatan yang ditinjau dari sisi dampak yang ditimbulkan terhadap perubahan perilaku masyarakat secara berkesinambungan; realisasi program CSR oleh TBBM Lhokseumawe yang dimaksud relatif telah efektif dan efisien meletakkan fondasi yang kuat bagi masyarakat setempat dalam transformasi paradigma dan etos kewirausahaan secara mandiri pasca pelaksanaan kegiatan. Pelaksanaan kegiatan berlandaskan kemitraan yang melibatkan berbagai komponen stakeholder dengan target penerima manfaat kepada kelompok masyarakat miskin setempat telah berhasil menciptakan sebuah sistem pemberdayaan masyarakat yang berkelanjutan melalui penguatan modal sosial, intelektual dan organisasional yang berlaku. Aspek modal organisasional merupakan tantangan terbesar dalam capaian dan konsistensi keberlangsungan program terhadap kehidupan ekonomi dan sosial masyarakat setempat. Optimalisasi kelembagaan ekonomi desa menjadi isu sentral yang menjadi prioritas untuk ditindaklanjuti sehingga dapat menjamin keberlanjutan hingga ke generasi wirausaha di milenial lainnya.
\end{abstract}

Kata kunci: CSR, Pemberdayaan Masyarakat, TBBM Lhokseumawe, Kecamatan Banda Sakti

\begin{abstract}
This paper qualitatively discusses relevant outcomes resulted from the implementation of CSR by PT. PERTAMINA (Persero) MOR I - TBBM Lhokseumawewhich was conducted in Subdistrict of Banda Sakti at Lhokseumawe City on 2017. The realization of CSR consisted several activities: 1) Development of Dry Fish Industry Centers; 2) Capacity Building of the Community Concerned Tourism Group: Workshop on Disaster and Search and Rescue (SAR) for Volunteers and Tour Guides; 3) Health Services: Basic Life Assistance Training (BHD) for Volunteers. 4) Decopage Souvenir Business Development; 5) New Entrepreneurship Development Training in Screen Printing and Repair of Air Conditioning Machines for School Dropout Productive Workers. Referring to the achievement of the implementation of activities in terms of the impact that are reflected in changes of community behavior on an ongoing basis; the realization of the CSR program by TBBM Lhokseumawe is considered relatively effective and efficient in building a strong foundation for local communities leading to the transformation of the paradigm and entrepreneurial ethos independently after the implementation of activities. The implementation of activities based on partnerships involving various components of stakeholders with the target beneficiaries to local poor groups has succeeded in creating a sustainable community empowerment system through the strengthening of prevailing social, intellectual and organizational capital. The aspect of organizational capital is the biggest challenge in the achievement and consistency of program sustainability towards the economic and social life of the local community. Optimizing village economic institutions is a central issue that is a priority to be followed up so as to ensure sustainability to the next generation of entrepreneurial entrepreneurs.
\end{abstract}




\section{PENDAhUluan}

Pembangunan suatu negara bukan hanya tanggung jawab pemerintah saja, setiap warga negara berperan untuk mewujudkan kesejahteraan sosial dan peningkatan kualitas hidup masyarakat. Ada tiga golongan yang berperan penting dalam pembangunan sebuah negara: Pemerintah (Government), Masyarakat (Citizen/People/ Community) dan Dunia Usaha (Corporate). Dunia usaha harus berperan mendorong pertumbuhan ekonomi yang sehat dengan mempertimbangan pula masyarakat dan lingkungan hidup. Nantinya sinergi antara pemerintah, masyarakat dan dunia usaha ini akan membentuk pembangunan ekonomi suatu daerah.

Pembangunan ekonomi daerah adalah suatu proses dimana pemerintah daerah dan masyarakatnya mengelola sumber daya - sumber daya yang ada dan membentuk suatu pola kemitraan antara pemerintah daerah dan sektor swasta untuk menciptakan lapangan kerja baru dan merangsang perkembangan kegiatan ekonomi (pertumbuhan ekonomi) dalam wilayah tersebut (Arsyad, 1999).

Pembangunan ekonomi daerah berorientasi pada proses. Suatu proses yang melibatkan pembentukan institusi baru, pembangunan industri alternatif, perbaikan kapasitas tenaga kerja yang ada untuk menghasilkan produk yang lebih baik, identifikasi pasar-pasar baru, dan transformasi pengetahuan (Adisasmita, 2005).

Salah satu upaya untuk meningkatkan pembangunan ekonomi daerah ini dengan cara implementasi program CSR (Corporate Social Responsibility) atau tanggung jawab sosial perusahaan adalah komitmen bisnis untuk berkontribusi dalam pembangunan ekonomi berkelanjutan, bekerja dengan para karyawan perusahaan, keluarga karyawan, dan masyarakat setempat (lokal) dalam rangka meningkatkan kualitas kehidupan. Konsep tanggung jawab sosial perusahaan (CSR) dapat dipandang sebagai salah satu upaya membangun relasi yang baik atau harmonis dengan masyarakat sekitar.

Salah satu penerapan CSR yang diharapkan mampu meningkatkan pembangunan ekonomi daerah seperti yang dilakukan PT. Pertamina dengan masyarakat yang ada di Kecamatan Banda Sakti Kota Lhokseumawe. Sejak terbentuk pada tahun 2001, hingga saat ini Kota Lhokseumawe dibagi menjadi 4 kecamatan (Kecamatan Banda Sakti, Kecamatan Muara Satu, Kecamatan Muara Dua dan Kecamatan Blang Mangat), 9 mukim, 68 gampong/desa, dan 259 dusun. Luas Kota Lhokseumawe yaitu 181,06 Km2 yang sebagian besar lahan digunakan untuk pemukiman penduduk.
Jumlah penduduk Kota Lhokseumawe pada tahun 2014 adalah sebanyak 187.455 jiwa terdiri atas 93.403 jiwa laki-laki dan 94.052 jiwa perempuan. Kecamatan Banda Sakti adalah kecamatan dengan jumlah penduduk terbanyak dengan proporsi sekitar 43 persen dari total penduduk Lhokseumawe atau 80.769 jiwa. Pada tahun 2014 tercatat jumlah pencari kerja di Kota Lhokseumawe adalah sebanyak 2.213 orang terdiri dari 842 laki-laki dan 1.371 perempuan. Dari jumlah ini, sekitar $29 \%$ diantaranya berpendidikan sarjana muda (D3) atau sarjana (Lhokseumawe dalam Angka, 2015).

Kecamatan Banda Sakti merupakan wilayah dengan potensi wisata pantai yang menawan, memiliki penduduk terbanyak di Kota Lhoksemawe dengan profesi penduduk terbanyaknya sebagai nelayan. Dengan daya dukung luas wilayah yang cukup memadai dan panorama alam yang indah, dengan kuantitas jumlah nelayan yang cukup signifikan, wilayah kecamatan ini sangat berpotensi untuk jadi zona wisata, sentra perikanan yang bisa memenuhi kebutuhan pangan dan meningkatkan kondisi ekonomi masyarakat menuju wilayah desa-desa wisata yang mandiri. Namun ironinya berdasarkan hasil kajian yang dilakukan CESD (2014) tentang Need Assesment dan Social Mapping di Desa Hagu Selatan, Hagu Tengah, dan Hagu Barat Laut Kecamatan Banda Sakti Kota Lhokseumawe yang merupakan wilayah Ring I PT. Pertamina (Persero) TBBM Lhokseumawe. Hasil kajian tersebut menunjukkan bahwa salah satu permasalahan klasik masyarakat adalah seputar angka pengangguran yang ada di wilayah tersebut dan sulitnya lapangan pekerjaan menjadi masalah yang penting untuk segera diselesaikan. Keberadaan pemuda atau golongan usia produktif yang tidak berpenghasilan dirasakan akan menjadi beban desa dan berhubungan dengan potensi narkoba, kriminalitas dan potensi konflik. Mentalitas masyarakat dalam hal ketergantungan terhadap kesempatan kerja yang ada, dalam hal ini mengandalkan untuk bisa masuk ke dalam sektor industri sebagai buruh, seharusnya dapat dihilangkan atau dikurangi.

Kondisi SDM penduduk wilayah CSR mengacu pada profil kecamatan dan potensi desa dimana masih tinggi jumlah penduduk yang tidak menyelesaikan sekolah dasar, dan warga yang menamatkan pendidikan SMP, dan SMA dalam jumlah yang relatif kecil, hanya sebagian kecil dari jumlah penduduk yang bisa menamatkan pendidikan tinggi. Hal ini menunjukkan adanya kesenjangan pendidikan yang sangat tajam. Sebagian besar penduduk bekerja di sektor non formal (2.203 orang) dan tingginya angka pengganguran. Pada musim hujan/disertai angin, penduduk tidak melakukan aktivitas melaut dan berkonsentrasi pada pemenuhan kebutuhan sehari-hari melalui perkebunan, dan 
peternakan. Budidaya hasil perikanan masih bersifat tradisional, yang jauh dari sentuhan ipteks.

Oleh karena itu, pendekatan pemberdayaan masyarakat yang dilaksanakan dengan CSR dari PT. Pertamina (Persero) MOR I - TBBM Lhokseumawe kepada masyarakat di Kecamatan Banda Sakti ini relatif berhasil dalam memfasilitasi beberapa permaslahan terkait dengan keterbatasan kapasitas profesional dan teknis masyarakat dalam optimalisasi sumberdaya lokal yang dapat membawa manfaat ekonomi. Upaya ini menjadi langkah strategis bagi masyarakat Kecamatan Banda Sakti dalam upaya meningkatkan kesejahteraan melalui pengelolaan sumber daya alam setempat secara berkelanjutan di sektor-sektor industri khususnya industri kreatif serta perbaikan kapasitas pasar tenaga kerja melalui pelatihan-pelatihan kewirausahaan.

\section{HASIL DAN PEMBAHASAN}

\subsection{Realisasi dan Capaian}

Landasan pelaksanaan program CSR oleh PT. Pertamina (Persero) RU III adalah UU Nomor 40 tahun 2007 pasal 74 dan PP Nomor 47 tahun 2012 Pasal 2. Bidang implementasi CSR oleh PT. Pertamina Persero) MOR I - TBBM Lhokseumawe ini dilakukan dalam 4 bidang yakni pemberdayaan masyarakat dalam sektor ekonomi usaha mikro dan kecil, lingkungan, dan kesehatan.. Aktivitas dan program aksi yang dilaksanakan pada tahun 2017 mengangkat tema "Menuju Kota Lhokseumawe sebagai Destinasi Wisata Madani" terdiri atas 5 (lima) rangkaian kegiatan utama, yaitu: ) Pengembangan Sentra Industri Ikan Kering; 2) Peningkatan Kapasitas Kelompok Masyarakat Peduli Wisata: Workshop Kebencanaan dan Search and Rescue (SAR) bagi Relawan dan Pemandu Wisata; 3) Pelayanan Kesehatan: Pelatihan Bantuan Hidup Dasar (BHD) untuk Relawan. 4) Pengembangan Usaha Souvenir Decopage; 5) Pelatihan Pengembangan Wirausaha Baru di Bidang Sablon dan Reparasi Mesin Penyejuk Udara (Air Conditioner/AC). Rangkaian kegiatan dapat dilihat pada gambar 1 berikut:
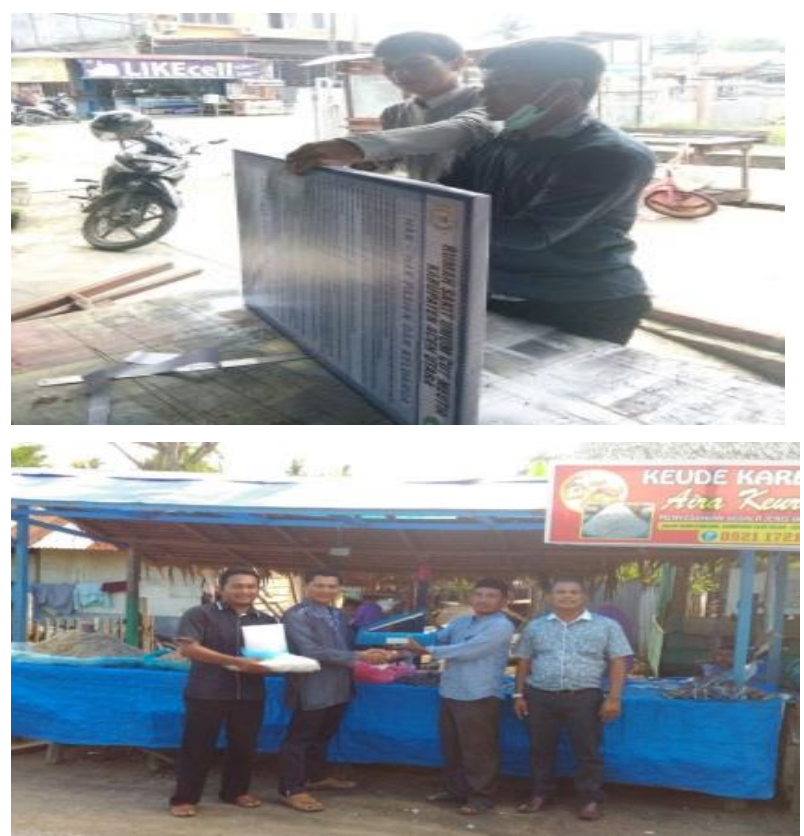


Gambar 1. Rangkaian Kegiatan CSR Bersama Masyarakat Kecamatan Banda Sakti Kota Lhokseumawe

\subsection{Kebermanfaatan dan Keberlanjutan}

Tanggung jawab sosial perusahaan sebagai salah satu peran BUMN untuk turut membantu pengembangan usaha kecil/koperasi, menjadi hal yang krusial dilakukan seiring dengan tuntutan dan kesadaran masyarakat akan pentingnya kualitas hidup yang ideal. Kontribusi BUMN terhadap terciptanya ketangguhan dan kemandirian ekonomi rakyat melalui upaya kemitraan sebagai pelaksanaan tanggung jawab sosial perusahaan, diharapkan dapat menberikan dampak signifikan terhadap peningkatan kesejahteraan rakyat. Implementasi kegiatan CSR yang benar, tepat dan berkelanjutan menjadi harapan besar bagi PT. Pertamina (Persero) untuk mewujudkan keseimbangan yang harmonis antara kepentingan ekonomi, sosial dan lingkungan, yang pada akhirnya menciptakan kehidupan masyarakat yang lebih sejahtera dan mandiri serta melibatkan semangat semua pihak secara terus menerus.

Bidang Lingkungan sebanyak 1 kegiatan yakni Peningkatan kapasitas kelompok masyarakat peduli 
wisata: Workshop Kebencanaan dan SAR bagi Relawan. Dari sisi kewilayahan, wilayah program CSR merupakan daerah pesisir yang sangat berpotensi terjadinya rawan bencana abrasi dan banjir setiap tahun. Sementara itu kepedulian masyarakat dalam menjaga kelestarian lingkungan relatif masih kurang. Di sisi yang lain, rendahnya budaya dan kemampuan masyarakat dalam mekanisme mitigasi bencana alam sering menimbulkan kerusakan pada simpul-simpul produktivitas sosio-ekonomi masyarakat, yang berujung pada keterpurukan kualitas dan kenyamanan hidup masyarakat. Bencana abrasi dan banjir merupakan permasalahan yang cukup serius di kawasan wisata bahari Pantai Ujong Blang Kota Lhokseumawe. Sehingga perlu ada upaya mitigasi bencana melalui rehabilitasi dan konservasi wilayah hutan mangrove di muara Pantai Ujong Blang sebagai benteng penahan abrasi dan bencana tsunami. Realisasi pelaksanaan rehabilitasi dan konservasi ini mencakup penanaman bibit pohon mangrove sebanyak 10.000 batang di areal konservasi hutan mangrove setempat yang dilakukan oleh Kelompok Tani Mangrove Banda Sakti. Di sisi penguatan kapasitas mitigasi bencana, PT. PERTAMINA (Persero) MOR I - TBBM Lhokseumawe juga melakukan aktivitas pelatihan pelestarian lingkungan dan kesiapsiagaan terhadap bencana berbasis komunitas Sadar Lingkungan dan Siaga Bencana. Edukasi pelestarian lingkungan dan ekologi hutan mangrove sekaligus kampanye kesiapsiagaan bencana kepada masyarakat di daerah yang rentan bencana telah mengubah paradigma dan kompetensi Masyarakat khususnya komunitaskomunitas penerima manfaat dalam menjaga keberlanjutan kawasan hutan mangrove serta kesiapan mereka dalam antisipasi risiko bencana yang sewaktuwaktu bisa terjadi.

Bidang Sosial Ekonomi - Industri Kreatif sebanyak 4 kegiatan yakni Pengembangan usaha kecil produktif bagi pemuda: Pengembangan usaha souvenir Decopage; Pengembangan usaha kecil produktif bagi pemuda: Pelatihan Pengembangan Usaha Sablon; Pengembangan usaha kecil produktif bagi pemuda: Pengembangan Usaha Service AC; dan Pengembangan demplot sentra perikanan: Pengembangan kemasan produk perikanan. Permasalahan yang timbul di masyarakat Kecamatan Banda Sakti adalah rendahnya budaya kerja dan produktivitas ekonomi masyarakat menyebabkan rendahnya pendapatan perkapita dan pendapatan keluarga. Padahal potensi alam dan dukungan program dan komitmen pemerintah dan institusi lain relatif cukup tinggi. Selain itu, belum terberdayanya lembaga-lembaga ekonomi masyarakat, UKM dan industri kerajinan kreatif-inovatif rumah tangga karena terbatasnya akses kepada sumber daya produktif, terutama permodalan, pasar, dan informasi dan teknologi. Selain itu rendahnya kesadaran, pengetahuan, keterampilan, dan keterlibatan elemen masyarakat dalam praktis kepariwisataan secara holistik berbasis pada wisata alam, budaya masyarakat, dan perikanan. Keempat kegiatan pemberdayaan diatas merupakan kegiatan yang riil dibutuhkan masyarakat untuk mengembangkan potensi sumberdaya alam, dan peluang usaha yang dibutuhkan masyarakat.

Salah satu output dari pelaksanaan pemberdayaan masyarakat ini adalah berdirinya Sentra Pemasaran Ikan Kering bagi produk kuliner ikan kering yang dihasilkan oleh penerima manfaat dengan nama "Kedeu Kareng - Aira Keureng". Keberadaan sentra ini selain menjadi motor penggerak bagi tumbuh-kembangnya industri ikan kering di Kecamatan Banda Sakti juga memberikan stimulus bagi pihak stakeholder lainnya dalam upaya pengembangan infrastruktur pemasaran hasil perikanan khususnya di wilayah setempat

Pemberdayaan usaha produktif bagi pemuda ini merupakan langkah nyata untuk membuka lapangan kerja dan menyerap pengangguran yang ada. Pengembangan usaha souvenir terutama dijalankan khususnya oleh kaum wanita baik ibu-ibu ataupun anak remaja merupakan optimalisasi peluang yang berlandaskan kearifan lokal yang berbasis kelautan. Selanjutnya pengembangan usaha sablon dan service AC umumnya dilakukan oleh kaum laki-laki, tentunya banyak menyerap tenaga kerja. Pelatihan dibidang keterampilan berwirausaha ini sangat cocok diterapkan di Kecamatan Banda Sakti ini mengingat banyaknya angkatan kerja yang tidak lulus SD, dan relatif banyak yang menamatkan hingga jenjang SMP dan SMA.

Implementasi CSR oleh PT. PERTAMINA (Persero) MOR I - TBBM Lhokseumawe terkait pengembangan desa wisata mandiri di Kecamatan Banda Sakti merupakan hilirisasi dari berbagai kajian relevan yang menggarisbawahi keterlibatan masyarakat lokal merupakan unsur utama dalam pengelolaan Desa Wisata termasuk pemberdayaan potensi ekonomi kepada sektor industri mikro dan kecil yang berada di wilayah setempat yang mendukung terciptanya eksositem desa wisata secara berkelanjutan. Penguatan pranata sosial yang berlaku didalam kehidupan warga desa di Kecamatan Banda Sakti menjadi turut menumbuhkembangkan rasa memiliki (sense of belonging) terhadap perkembangan pariwisata di desanya, sebagai pengelola sekaligus penerima manfaat. Selain itu, CSR oleh PT. PERTAMINA (Persero) MOR I - TBBM Lhokseumawe juga memberikan induksi pengenalan dan pendampingan pemanfaatan strategi promosi dan pemasaran dengan kombinasi media promosi online (media digital, laman internet) maupun offline (pameran, brosur) yang mampu menggugah dan mendorong kesadaran masyarakat khususnya generasi muda setempat dalam mempromosikan potensi wisata dan ekonomi di Kecamatan Banda Sakti melalui unggahan foto dan berita (newsfeed) di laman akun media sosial mereka. Sehingga, pemanfaatan strategi promosi melalui publikasi media sosial dan laman internet seperti ini semakin mengenalkan kepada publik mengenai keberadaan dan aktivitas-aktivitas desa wisata mandiri di lingkungan Kecamatan Banda Sakti.

Masyarakat nelayan pesisir pada umumnya didominasi pada golongan miskin. Umumnya sumber kemiskinan 
nelayan menjadi dua faktor antara lain: a) Faktor alamiah, faktor alamiah berkaitan dengan fluktuasi musim-musim penangkapan dan struktur alamiah sumber daya ekonomi desa dan; b) Faktor non-alamiah berhubungan dengan keterbatasan daya jangkau teknologi penangkapan, ketimpangan dalam sistem bagi hasil dan tidak adanya jaminan sosial tenaga kerja yang pasti, lemahnya penguasaan jaringan pemasaran dan belum berfungsinya koperasi nelayan yang ada, serta dampak negatif dari kebijakan modernisasi perikanan. Menurut hasil penelitian Retnowati (2011) menjelaskan bahwa dari sisi ekonomi hasil tangkapan nelayan masih jauh dari memadahi untuk memenuhi kebutuhan hidupnya. Hal ini disebabkan karena minimnya modal yang dimiliki nelayan, tekanan dari pemilik modal, sistem bagi hasil yang tidak adil, perdagangan atau pelelangan ikan yang tidak transparan (dikuasai tengkulak) dan otoritas tidak punya wibawa untuk mengatur dan menegakkan aturan. Serta pola atau budaya kerja yang masih apa adanya. Kondisi kemiskinan yang dialami nelayan menyebabkan mereka rentan konflik dan hanya menjadi objek. Hukum yang seharusnya memberikan perlindungan ternyata juga tidak optimal.

Penyebab kemiskinan nelayan di Indonesia sangatlah komplek, penyebab individual, keluarga, subbudaya, agensi maupun struktural saling berkaitan. Menurut Kusnadi, sebab-sebab pokok yang menimbulkan kemiskinan pada nelayan adalah: a) belum adanya kebijakan, strategi dan implementasi program pembangunan kawasan pesisir dan masyarakat nelayan yang terpadu di antara para pemangku kepentingan pembangunan; b) adanya inkonsistensi kuantitas produksi (hasil tangkapan), sehingga keberlanjutan aktivitas sosial ekonomi perikanan di desa-desa nelayan terganggu. Hal ini disebabkan oleh kondisi sumber daya perikanan telah mencapai kondisi "over fishing", musim paceklik yang berkepanjangan, dan kenaikan harga bahan bakar minyak (BBM); c) masalah isolasi geografis desa nelayan, sehingga menyulitkan keluarmasuk arus barang, jasa, kapital, dan manusia, yang mengganggu mobilitas sosial ekonomi; d) adanya keterbatasan modal usaha atau modal investasi, sehingga menyulitkan nelayan meningkatkan kegiatan ekonomi perikanannya; e) adanya relasi sosial ekonomi yang "eksploitatif" dengan pemilik perahu, pedagang perantara (tengkulak), atau pengusaha perikanan dalam kehidupan masyarakat nelayan; f) adalah rendahnya tingkat pendapatan rumah tangga nelayan, sehingga berdampak negatif terhadap upaya peningkatan skala usaha dan perbaikan kualitas mereka. (Direktorat Pemberdayaan Masyarakat Pesisir, 2006)

Program CSR PT. Pertamina di Kecamatan Banda Sakti ini sejalan dengan paradigma penanggulangan kemiskinan, Komisi Penanggulangan Kemiskinan (KPK) RI yang dibentuk melalui Keppres Nomor 124/2001, j.o. Keppres Nomor 8/2002, j.o. Keppres Nomor 34/2002 menetapkan Pemberdayaan Masyarakat sebagai strategi penanggulangan kemiskinan. Strategi ini dilaksanakan melalui dua upaya, yaitu:

1. Upaya pengurangan beban pengeluaran masyarakat miskin dilakukan melalui penajaman alokasi APBN, yaitu melalui :

a. Bantuan Langsung Masyarakat (BLM) dengan melakukan tiga pemberdayaan yaitu pada usahanya yang berupa bantuan teknis untuk permodalan dan pendampingan, pada manusianya yaitu berkaitan dengan pendidikan, pelatihan dan peningkatan kesehatan; dan pada lingkungannya yang berupa sarana-prasarana pendukung usaha atau kegiatan produktif masyarakat miskin.

b. Bantuan Operasional Pembangunan (BOP) kepada departemen/ LPND/instansi terkait untuk melakukan pembinaan teknis terhadap lembaga-lembaga di Tingkat Daerah. Pembinaan teknis yang diterapkan meliputi pembinaan kepada manusianya, usahanya, kelembagaannya, monitoring evaluasi dan pengendaliannya.

2. Upaya peningkatan produktivitas dapat dilakukan melalui pengembangan dan pemberdayaan usaha masyarakat terutama Usaha Mikro, Kecil dan Menengah yang meliputi penajaman program, pendanaan dan pendampingan.

Selanjutnya implementasi kegiatan CSR di Kecamatan Banda Sakti ini telah berjalan sesuai dengan 3 prinsip dasar dari konsep CSR yang dikenal dengan istilah triple bottom lines yang dikenal sebagai $3 \mathrm{P}$ (people, profit, planet) yaitu kepedulian perusahaan yang menyisihkan sebagian keuntungannya (profit) bagi kepentingan pembangunan manusia (people) dan lingkungan (planet) agar keberadaan perusahaan dapat tumbuh dan berkelanjutan. Ketiga prinsip ini telah dijalankan dengan baik dengan mensinergi ketiga elemen ini yang merupakan kunci dari konsep pembangunan berkelanjutan (sustainable development). Perusahaan dalam hal ini diberitanggung jawab sosial untuk ikut mensejahterakan warga negara yang ada di sekitarnya.

Hambatan nelayan terhadap tingkat penghasilannya juga terjadi disaat musim paceklik ikan tiba, misalnya saat cuaca buruk, badai dan sebagainya. Untuk itu, perlu ada strategi lain untuk meningkatkan taraf perekonomian keluarga nelayan yakni dengan strategi diversifikasi pekerjaan. Artinya nelayan tetap dibekali keterampilan lain yang bisa dilakukan pada saat tidak bisa melaut seperti keterampilan berkebun, beternak, mengelola tambak, menjadi buruh dan lain-lain. Diversifikasi pekerjaan ini dilakukan terutama pada saat musim paceklik ikan tiba, sehingga diharapkan sumber-sumber pendapatan nelayan semakin beragam dan akses ke sumber daya ekonomi akan lebih luas dan fleksibel.

Tidak hanya itu, menurut hasil penelitian Goso dan Anwar (2017) bahwa kemiskikan nelayan tradisional disebabkan oleh tiga hal yakni faktor kualitas 
sumberdaya manusia, faktor ekonomi dan faktor kelembagaan. Kualitas suberdaya yang rendah terlihat dari minimnya tingkat pendidikan, keterbatasan keterampilan yang dimiliki (keterampilan alternative) oleh nelayan. Ketidakberdayaan ekonomi nelayan terlihat dari asset-aset yang dimiliki; kepemilikan tanah, modal kerja, serta teknologi modern nelayan serta ketidakberdayaan dalam bidang kelembagaan di buktikan dengan lemahnya peranan lembaga dalam berperan untuk meningkatkan kesejahteraan anggotanya melalui kegiatan ekonomi nelayan tradisional seperti keberadaan Koperasi Nelayan yang hanya bergerak dalam bidang simpan pinjam.

Mengingat upaya peningkatan kesejahteraan masyarakat pesisir ini tidaklah instan dan justru memerlukan perhatian dan perencanaan yang matang dan terencana dari tiga yakni pemerintah, masyarakat, dan sektor swasta. Untuk itu, keberlanjutan implementasi program dari CSR ini di Kecamatan Banda Sakti ini bisa terus dilaksanakan khususnya dibidang kelembagaan yang memang masih sangat kurang. Upaya pembentukan BUMD, KUD dan pusat pemasaran hasil produk kerajinan, diversifikasi produk hasil perikanan dan jasa wisata pantai.

\section{KESIMPULAN}

Kecamatan Banda Sakti adalah kecamatan yang memiliki penduduk terbanyak, namun dengan kondisi sosial eknomi termiskin di Kota Lhokseumawe. Padahal dengan daya dukung luas wilayah yang cukup memadai dan panorama alam yang indah, dengan kuantitas jumlah nelayan yang cukup signifikan, wilayah Kecamatan Banda Sakti ini sangat berpotensi untuk jadi zona wisata, sentra perikanan yang bisa memenuhi kebutuhan pangan dan meningkatkan kondisi ekonomi masyarakat menuju wilayah desa-desa wisata yang mandiri. Dengan adanya kegiatan CSR PT. Pertamina kecamatan ini diharapkan mampu berperan dalam membantu meningkatkan kesejahteraan sosial, dan peningkatan kualitas hidup masyarakat yang mencakup: 1) Pengembangan Sentra Industri Ikan Kering; 2) Peningkatan Kapasitas Kelompok Masyarakat Peduli Wisata: Workshop Kebencanaan dan Search and Rescue (SAR) bagi Relawan dan Pemandu Wisata; 3) Pelayanan Kesehatan: Pelatihan Bantuan Hidup Dasar (BHD) untuk Relawan. 4) Pengembangan Usaha Souvenir Decopage; 5) Pelatihan Pengembangan Wirausaha Baru di Bidang Sablon dan Reparasi Mesin Penyejuk Udara (Air Conditioner/AC) Bagi Angkatan Kerja Produktif Putus Sekolah.

Pelaksanaan kegiatan ini telah tepat sasaran dengan target kepada optimalisasi kapasitas soft-skills dan hard-skilss kelompok masyarakat miskin dengan mengembangkan dan mensinergikan peran pemerintah, masyarakat dan swasta melalui strategi pemberdayaan masyarakat untuk meningkatkan kesejahteraan masyarakat. Kebermanfaatan kegiatan ini telah dirasakan langsung oleh masyarakat, namun upaya pembangunan ekonomi daerah pesisir ini perlu keberlanjutan untuk memaksimalkan segala potensi sumberdaya alam dan manusia, khususnya pada aspek kelembagaan ekonomi yang masih sangat kurang di Kecamatan Banda Sakti Kota Lhokseumawe.

\section{DAFTAR PUSTAKA}

Adisasmita, R. (2005). Dasar-dasar Ekonomi Wilayah. Penerbit Graha Ilmu.

Arsyad, L. (1999). Pengantar perencanaan dan pembangunan ekonomi daerah. Yogyakarta: BPFE.

BPS. (2017). Kecamatan Banda Sakti Dalam Angka 2017

BPS. (2018). Kota Lhokseumawe Dalam Angka 2018

Direktorat PMP. (2006). 6 Tahun Program PEMP, Sebuah Refleksi. Direktorat Pemberdayaan Masyarakat Pesisir, Direktorat Jenderal Kelautan, Pesisir dan Pulau-pulau Kecil. Jakarta: Departemen Kelautan dan Perikanan.

Goso, dan Anwar, S. M. Kemiskinan Nelayan Tradisional Serta Dampaknya Terhadap Perkembangan Kumuh. Jurnal Manajemen, Vol. 03 No. 01 Februari, ISSN 2339-1510

Retnowati, E. (2011). Nelayan Indonesia Dalam Pusaran Kemiskinan Struktural (Perspektif Sosial, Ekonomi Dan Hukum). Jurnal Perspektif. Volume XVI No. 3 Tahun 2011 Edisi Mei. 